\title{
Desain, Pelaksanaan dan Evaluasi Pembelajaran pada Sekolah Menengah
}

\author{
Siti Julaeha', Muhammad Maky², Uus Ruswandi ${ }^{3}$ \\ 123 UIN Sunan Gunung Djati Bandung \\ sitijuleikha425@gmail.com , uusruswandi@uinsgd.ac.id
}

\begin{abstract}
New innovations in view of teaching and learning implementation, including PAI subjects have consequences for teachers to increase their roles and competencies, because the teaching and learning process and student learning outcomes are largely determined by the role of competent teachers in making and implementing the learning designs that have been made. Competent teachers will be better able to create an effective learning environment and will be better able to manage their classes, so that student learning outcomes are at an optimal level. One of the teacher's roles in the teaching and learning process is as an evaluator. In one teaching and learning process the teacher should be a good evaluator. This activity is intended to determine whether the goals that have been formulated have been achieved or not, and whether the material being taught is quite appropriate. The design, implementation and evaluation of PAI learning at the secondary school level is carried out in collaboration with all teachers and the school community. More than that, PAI religious teachers have a more important role in fostering the morals of students through the learning process by making learning designs that are attractive and easy to understand and implement by students. Before teaching the teacher makes plans in the form of lesson plans, and in implementing learning the teacher becomes an example for students, the teacher always instills a disciplined attitude in learning, teaches respect for others and instills a sense of responsibility to study hard. The final value of all these processes is evaluation, one of which is by conducting an assessment, both on the process and on student learning outcomes.
\end{abstract}

Keywords: design, implementation and evaluation of PAI learning

\section{ABSTRAK}

Inovasi baru terhadap pandangan pelaksanaan belajar mengajar termasuk pada mata pejaran PAI membawa konsekuensi kepada guru untuk meningkatkan peranan dan kompetensinya, karena proses belajar mengajar dan hasil belajar siswa sebagian besar ditentukan oleh peran guru yang kompeten dalam membuat dan melaksanakan desain pembelajaran yang telah dibuat. Guru yang kompeten akan lebih mampu menciptakan lingkungan belajar yang efektif dan akan lebih mampu mengelola kelasnya, sehingga hasil belajar siswa berada pada tingkat optimal. Salah satu peran guru dalam proses belajar mengajar adalah sebagai evaluator. Dalam satu kali proses belajar mengajar guru hendaknya menjadi seorang evalutor yang baik. Kegiatan ini dimaksudkan untuk mengetahui apakah tujuan yang telah dirumuskan itu tercapai atau belum, dan apakah materi yang diajarkan sudah cukup tepat. Desain, pelaksanaan dan evaluasi pembelajaran PAI di tingkat ekolah menegah dilakukan dengan cara kerjasama semua guru dan civitas lembaga sekolah. Lebih dari pada itu guru agama PAI mempunyai lebih peran penting dalam membina akhlak peserta didik melalui proses pembelajaran dengan membuat desain pembelajaran yang menarik dan mudah dipahami serta dilaksanakan oleh peserta didik. Sebelum mengajar guru membuat 


\section{Jurual Dirosah Islamigah}

Volume 4 Nomor 2 (2022) 226-249 P-ISSN 2656-839x E-ISSN 2716-4683 DOI: 10.17467/jdi.v4i2.909

perencanaan berupa RPP, dan dalam pelaksanaan pembelajaran guru menjadi teladan bagi peserta didik, guru senantiasa menanamkan sikap disiplin dalam pembelajaran, mengajarkan bersikap rasa hormat kepada orang lain dan menanamkan rasa tanggung jawab untuk rajin belajar. Nilai akhir dari semua proses tersebut adalah evaluasi, salah satunya adalah dengan mengadakan penilaian, baik terhadap proses maupun terhadap hasil belajar siswa.

Kata Kunci: desain, pelaksanaan dan evaluasi pembelajaran PAI

\section{PENDAHULUAN}

Pendidikan Agama Islam di Sekolah Menengah adalah suatu keniscayaan untuk dilaksanakan, karena melalui mata pelajaran Pendidikan Agama Islam peserta didik di Sekolah Menengah akan mendapatkan pengetahuan agama sebagai penguat pengetahuan agama yang telah diperolehnya dari lingkungan keluarga maupun masyarakat tempat peserta didik tinggal. Pengetahuan agama Islam ini selanjutnya diterapkan di dalam kehidupan sehari-hari peserta didik melalui bimbingan, dorongan, asuhan maupun suri tauladan dari para guru Pendidikan Agama Islam di sekolah beserta para guru yang lainnya.

Pendidikan Agama Islam sebagai suatu proses ikhtiyariyah mengandung ciri dan watak khusus, yaitu proses penanaman, pengembangan dan pemantapan nilainilai keimanan yang menjadi fundamental spritual manusia dimana sikap dan tingkah lakunya termanifestasikan menurut kaidah-kaidah agamanya. Nilai-nilai keimanan seseorang adalah keseluruhan pribadi yang menyatakan diri dalam bentuk tingkah laku lahiriah dan rohaniah, dan merupakan tenaga pendorong atau penegak yang fundamental, bagi tingkah laku seseorang. ${ }^{1}$

Berdasarkan undang-undang sistem Pendidikan Nasional Nomor 20 tahun 2003 Menjelaskan bahwa: Pendidikan nasional bertujuan untuk mengembangkan potensi peserta didik agar menjadi manusia Indonesia seutuhnya yaitu manusia yang beriman dan bertaqwa kepada Tuhan Yang Maha Esa, memiliki pengetahuan dan keterampilan, berbudi pekerti yang luhur, sehat jasmani dan rohani, berkepribadian yang mantap, cerdas, kreatif, mandiri dan memiliki rasa tanggung jawab. ${ }^{2}$

Pendidikan pada dasarnya merupakan interaksi antara pendidik dengan peserta didik. Seiring dengan berkembangnya pendidikan dan sistem pendidikan di Indonesia, maka seluruh elemen masyarakat utamanya yang terkait langsung dengan kegiatan pendidikan dituntut untuk lebih kreatif dan profesional untuk mengembangkan pendidikan. Selain itu, para pelaku pendidikan juga diharapkan dalam melaksanakan pendidikan sesuai dengan prosedur yang telah diterapkan bersama sesuai dengan kebutuhan dan tantangan pendidikan.

Untuk itulah perlu adanya perencanaan pembelajaran yang matang untuk menghadapi tantangan-tantangan yang muncul seiring dengan berkembangnya

1 M. Arifin, Kapita Selekta Pendidikan (Cet. IV; Jakarta: Bumi Aksara, 2000), 214.

${ }^{2}$ Fadhlan Mudhafir, Krisis Dalam Pendidikan Islam (Cet. I; Jakarta: Al-Mawardi Prima, 2000), 1 . 


\section{Jurual Dirosah Islamigah}

Volume 4 Nomor 2 (2022) 226-249 P-ISSN 2656-839x E-ISSN 2716-4683 DOI: $10.17467 /$ jdi.v4i2.909

waktu. Membuat desain pembelajaran merupakan tahap awal yang harus dilaksanakan untuk melaksanakan proses pembelajaran karena keberhasilan pelaksanaan pembelajaran sangat bergantung pada sejauh mana pembelajaran itu didesain atau direncanakan, sebaliknya pembelajaran yang tidak didesain secara sistematis tidak akan mendapatkan hasil pembelajaran yang maksimal.

Desain pembelajaran membantu guru untuk melaksanakan tugasnya sebagai pengajar. Desain yang disusun oleh guru merupakan indikator yang menunjukkan bahwa guru tersebut telah menguasai bahan pelajaran yang akan diberikan kepada peserta didik. Desain pembelajaran yang baik, akan menjadikan pembelajaran lebih berkualitas dan bermakna bagi peserta didik. ${ }^{3}$

Pengalaman empirik peserta didik sejak menjadi murid sekolah dasar, sekolah menengah pertama dan menengah atas dapat diidentifikasi melalui berbagai jenis pengajaran/pembelajaran para gurunya. Diantara para pengajar itu ada yang mempersiapkan seluruh kegiatan belajar-mengajar secara khusus, lengkap, jauh sebelum memulai tatap muka dan ada pula hanya secara umum, seadanya, dan untuk setiap kali pengajaran. Kelompok pengajar yang lain bahkan merasa tidak perlu membuat persiapan apapun sebelum mengajar. Kelompok yang terakhir ini langsung mengajar karena merasa telah dapat mengajar dengan baik apabila mengetahui topik yang akan diajarkan. Setiap pengajar (baik yang membuat persiapan atau tidak), harus selalu mencari cara untuk melaksanakan kegiatan instruksionalnya sebaikbaiknya.

Rendahnya mutu dan relevansi pendidikan dipengaruhi oleh sejumlah faktor, antara lain perencanaan pembelajaran yang tidak direncanakan dengan matang, kualitas proses pembelajaran yang masih rendah, serta hasil proses pembelajaran yang belum didukung oleh sistem pengujian dan penilaian yang efektif dan efisien sehingga mutu pendidikan belum dapat dimonitor secara objektif dan komprehensif.

Lembaga Pendidikan yang berkualitas merupakan sebuah dambaan setiap komponen masyarakat, baik komponen masyarakat sekolah yang terdiri dari peserta didik, pendidik dan tenaga kependidikan, maupun masyarakat dalam arti luas yaitu orang tua atau masyarakat lain pengguna pendidikan atau simpatisan yang menaruh perhatian besar terhadap kuantitas dan kualitas output pendidikan, yang pada akhirnya menggunakan jasa pendidikan yang di hasilkan oleh lembaga pendidikan yang berkualitas tersebut.

Berdasarkan uraian pemaparan diatas, penulis tertarik untuk mengkaji lebih dalam mengenai desain, pelaksanaan dan evaluasi pembelajaran Pendidikan Agama Islam dan Budi Pekerti di Sekolah Menengah.

\section{METODE PENELITIAN}

Dilihat dari jenis penelitiannya, penelitian yang digunakan adalah penelitian kualitatif. Pendekatan kualitatif menurut Bogdan dan Taylor dalam Tohirin prosedur penelitian yang menghasilkan data deskriptif berupa kata-kata tertulis atau lisan dari

\footnotetext{
${ }^{3}$ Muhammad Yaumi, Prinsip - Prinsip Desain Pembelajaran, (Jakarta: Kencana,2013), 4.
} 


\section{Jurual Dirosah Islamigah}

Volume 4 Nomor 2 (2022) 226-249 P-ISSN 2656-839x E-ISSN 2716-4683 DOI: 10.17467/jdi.v4i2.909

orang-orang dan perilaku yang diamati. ${ }^{4}$ Penelitian kualitatif dengan instrument library research. Data penelitian ini adalah data kualitatif berupa uraian, paparan dan tulisan yang dirujuk dari sumber yang berikaitan dengan masalah penelitian, baik dalam bentuk buku, jurnal, dan artikel.

Metode penelitian ini deskriptif, yaitu memaparkan data dalam bahan pustaka sesuai kajian yang relevan. Teknik pengumpulan data yang yang dijadikan alat untuk mengumpulkan data dalam penelitian ini adalah teknik dokumenter: yakni, data digali melalui dokumen dari berbagai bahan pustaka, kemudian dianalisis dengan menggunakan analisis isi. dengan teknik studi dokumentasi. Menurut Sugiono studi dokumentasi yaitu teknik pengumpulan data dengan menghimpun dan menganalisa data dalam bentuk dokumen baik tertulis maupun gambar. ${ }^{5}$ Dengan teknik ini, data kualitatif diurutkan, dikategorisasi (dikelompokkan) data-datanya yang serupa, kemudian isinya dianalisis secara kritis sehingga dirumuskan formulasi yang konkret yang kemudian dijelaskan secara mendalam.

\section{PEMBAHASAN}

\section{Desain Pembelajaran Pendidikan Agama Islam dan Budi Pekerti}

\section{a. Pengertian Desain Pembelajaran Pendidikan Agama Islam dan Budi Pekerti}

Ada beberapa pendapat ahli mengenai definisi desain pembelajaran, atau dikenal juga dengan rancangan instruksional, rancangan pembelajaran, dan desain instruksional. Menurut Choirul Amin desain adalah kerangka bentuk, rancangan, motif, pola atau corak. Dedi Nurhadiat juga mengatakan bahwa desain adalah perencanaan untuk mewujudkan suatu gagasan. Sedangkan pembelajaran menurut menurut Dimyati dan Mudjiono, merupakan aktivitas pendidik atau guru yang terprogram melalui desain intruksional agar peserta didik dapat belajar secara aktif dan lebih menekankan pada sumber yang disediakan. ${ }^{6}$ Adapun menurut Slavin, learning is acquiring or getting of knowledge of a subject or a skill by study, experience, or instruction. ${ }^{7}$ Selanjutnya Zakiyah Daradjat kutip oleh Abdul Majid dan Dian Andayani, Pendidikan Agama Islam adalah suatu usaha untuk membina dan mengasuh peserta didik agar senantiasa dapat memahami ajaran Islam secara menyeluruh, lalu menghayati tujuan, yang pada akhirnya dapat mengamalkan serta menjadikan Islam sebagai pandangan hidup. ${ }^{8}$

Adapun menurut Relgeluth yang dikutip oleh St. Marwiyah, desain pembelajaran adalah proses untuk menentukan metode pembelajaran apa yang

\footnotetext{
4 Tohirin, Metode Penelitian Kualitatif dalam Pendidikan dan Bimbingan Konseling. (Jakarta : Raja Grafindo Persada, 2012), 4.

${ }^{5}$ Sugiyono, metode Penelitian Kombinasi (Mix Method). (Bandung : Alfabeta,2016), 236

${ }^{6}$ Hamzah B.Uno, Perencanaan Pembelajaran, (Jakarta: Bumi Aksara,2006), 4.

${ }^{7}$ Douglas Brown, Teaching by Principal: an Interaction Approach to Language Pedagogy, (USA: Person Education, 2007), 53.

${ }^{8}$ Abdul Majid dan Dian Andayani, Pendidikan Agama Islam Berbasis Kompetensi: Konsep dan Imlementasi Kurikulum 2004, (Bandung: Rosdakarya, 2004), 130.
} 


\section{Jurual Dirosah Islamigah}

Volume 4 Nomor 2 (2022) 226-249 P-ISSN 2656-839x E-ISSN 2716-4683 DOI: 10.17467/jdi.v4i2.909

paling baik dilaksanakan agar timbul perubahan pengetahuan dan keterampilan pada diri pengajar ke arah yang dikehendaki. ${ }^{9}$ Sedangkan menurut Briggs yang dikutip oleh Fatah Syukur NC, desain pembelajaran adalah rencana tindakan yang terintegrasi meliputi komponen tujuan, metode dan penilaian untuk memecahkan masalah atau memenuhi kebutuhan. ${ }^{10}$

Berdasarkan pemaparan para ahli diatas, peneliti dapat menyimpulkan bahwa desain pembelajaran pendidikan agama Islam adalah sebuah rancangan pembelajaran yang akan digunakan oleh guru Pendidikan Agama Islam untuk membina dan menyiapkan siswa agar dapat memahami dan mengamalkan nilai-nilai Islam dalam kehidupan sehari-hari yang terdiri dari kegiatan analisis, desain, pengembangan, implementasi, dan evaluasi.

\section{b. Fungsi Desain Pembelajaran Pendidikan Agama Islam dan Budi Pekerti}

Adapun fungsi-fungsi desain pembelajaran termasuk desain pembelajaran PAI yaitu sebagai petunjuk arah kegiatan dalam mencapai tujuan, sebagai pola dasar dalam mengatur tugas dan wewenang bagi setiap unsur yang terlibat dalam kegiatan, sebagai pedoman kerja guru maupun murid, sebagai alat ukur efektif tidaknya suatu pekerjaan, sebagai bahan penyusunan data agar terjadi keseimbangan kerja, menghemat waktu, tenaga, alat dan biaya, meningkatkan kemampuan pembelajar, sebagai sarana menghasilkan sumber belajar, dan sebagai sarana mengembangkan sistem belajar mengajar di kelas. ${ }^{11}$

Esensi desain pembelajaran mencakup komponen siswa, tujuan, metode, evaluasi, dan analisis topik. Menurut Morisson, Ross, dan Kemp seperti yang dikutip Dewi Salma Prawiradilaga, rincian komponen inti dari desain pembelajaran (siswa, tujuan pembelajaran, metode, dan penilaian) digambarkan dengan lingkaran, keempat komponen tersebut yang saling berpotongan satu sama lainnya. ${ }^{12} \mathrm{Hal}$ itu menunjukkan bahwa antara yang satu dengan yang lain haruslah memiliki fokus perhatian yang sama, selaras, serasi, dan seimbang agar pembelajaran dapat berlangsung sukses.

Berikut ini langkah-langkah dalam mendesain pembelajaran:

\section{Identifikasi tujuan pembelajaran (identity instructional goals)}

Sasaran akhir dari suatu pembelajaran adalah tercapainya tujuan umum pembelajaran tersebut oleh karena itu, setiap perancang harus mempertimbangkan secara mendalam tentang rumusan tujuan umum pengajaran yang ditentukan nya.

${ }^{9}$ St. Marwiyah, Perencanaan Pembelajaran Pendidikan Agama Islam, (Makassar: Aksara Timur,2015), 22.

${ }^{10}$ Fatah Syukur NC, Teknologi Pendidikan, (Semarang: Rasail Media Grup, 2008), 32.

${ }^{11}$ Bermawi Munthe, Desain Pembelajaran, (Yogyakarta: Insan Madani, 2012), 32.

12 Dewi Salma Prawiradilaga, Prinsip Desain Pembelajaran, (Jakarta: Prenada Media Grup, 2007), 17. 


\section{Jurual Dirosah Islamigah}

Volume 4 Nomor 2 (2022) 226-249 P-ISSN 2656-839x E-ISSN 2716-4683 DOI: $10.17467 /$ jdi.v4i2.909

Dick and Carrey (1985) dalam uno hamzah (2010:24) menjelaskan bahwa tujuan pengajaran adalah untuk menentukan apa yang dapat dilakukan oleh anak didik setelah mengikuti kegiatan pembelajaran. Rumusan tujuan umum pembelajaran menurut Dick and Carrey (1985) harus jelas dan dapat diukur.

Rumusan tujuan pembelajaran dapat dikembangkan baik dari rumusan tujuan pembelajaran yang sudah ada pada silabus maupun dari hasil analisis kinerja atau performance analysis. Rumusan tujuan pembelajaran dapat juga dihasilkan melalui proses analisis kebutuhan atau need analysis dan pengalaman-pengalaman tentang kesulitan-kesulitan belajar yang dihadapi oleh siswa. Selain itu, tujuan pembelajaran dapat juga dirumuskan dengan menggunakan analisis tentang cara seseorang melakukan tugas atau pekerjaan yang spesifik dan Persyaratan-persyaratan yang diperlukan untuk melakukan tugas dan pekerjaan tersebut. Cara ini dikenal dengan istilah analisis tugas atau task analysis

\section{Melakukan analisis instruksional (conducting a goal analysis)}

Setelah melakukan identifikasi tujuan pembelajaran, langkah selanjutnya adalah melakukan analisis instruksional, yaitu sebuah prosedur yang digunakan untuk menentukan keterampilan dan pengetahuan relevan dan diperlukan oleh siswa untuk mencapai kompetensi atau tujuan pembelajaran. Dalam melakukan analisis instruksional, beberapa langkah diperlukan untuk mengidentifikasi kompetensi, berupa pengetahuan (cognitive), keterampilan (psychomotor), dan sikap (atitudes) yang perlu dimiliki oleh siswa setelah mengikuti proses pembelajaran.

\section{Mengidentifikasi tingkah laku/karakteristik siswa (identity entry behaviour, characteristics)}

Mengidentifikasi tingkah laku atau karakteristik siswa merupakan hal yang perlu dilakukan untuk dijadikan salah satu bahan acuan dalam menerapkan model ini. Analisis konteks ini bisa meliputi keterampilan, kemampuan, bakat, gaya belajar, motivasi belajar,atau pun minat seorang siswa. Identifikasi yang akurat tentang karakteristik siswa yang akan belajar dapat membantu perancang program pembelajaran dalam memilih dan menentukan strategi pembelajaran yang akan digunakan.

\section{Merumuskan tujuan kinerja (write performance objective)}

Menurut Dick dan Carrey (1985) dalam uno hamzah (2010:27) menyatakan bahwa tujuan performansi terdiri atas:

(l) tujuan harus menguraikan apa yang akan dapat dikerjakan, atau diperbuat oleh anak didik;

(2) menyebutkan tujuan, memberikan kondisi atau keadaan yang menjadi syarat, yang hadir pada waktu anak didik berbuat;

(3) menyebutkan kriteria yang digunakan untuk menilai untuk perbuatan anak didik yang dimaksudkan pada tujuan. 


\section{Jurual Dirosah Islamigah}

Volume 4 Nomor 2 (2022) 226-249 P-ISSN 2656-839x E-ISSN 2716-4683 DOI: $10.17467 /$ jdi.v4i2.909

Gagne, Briggs, dan Mager menjelaskan bahwa fungsi performansi objektif adalah

(a)menyediakan suatu sarana dalam kaitannya dengan pembelajaran untuk mencapai tujuan;(b) menyediakan suatu sarana berdasarkan suatu kondisi belajar yang sesuai; (c) memberikan arah dalam mengembangkan pengukuran atau penilaian; (d) membantu anak didik dalam usaha belajarnya

\section{Pengembangan tes acuan patokan (develop criterian referenced test items)}

Tes acuan patokan terdiri dari soal yang menjadi syarat kecakapan siswa dalam tujuan, keberhasilan siswa dalam tes ini menentukan apakah siswa telah mencapai tujuan khusus atau belum, tes acuan patokan (criterian referenced test) disebut juga tes acuan tujuan (objective referenced test)

\section{Pengembangan strategi pembelajaran (develop instructional strategy)}

Strategi yang digunakan disebut dengan istilah strategi pembelajaran atau instruksional strategi. Bentuk bentuk strategi pembelajaran yang dapat digunakan dalam mengimplementasikan aktivitas pembelajaran yaitu aktivitas prapembelajaran, penyajian materi pembelajaran, dan aktivitas tindak lanjut dari kegiatan pembelajaran.

Pengembangan atau memilih materi pembelajaran (develop and select instructional materialis)

Dick and carrey (1985) menyarankan ada tiga pola yang dapat diikuti pengajar untuk merancang atau menyampaikan pembelajaran yaitu

A) Pengajar merancang bahan pembelajaran individual, semua tahap pembelajaran dimaksudkan ke dalam bahan, kecuali prates dan pascates.

B) Pengajar memilih dan mengubah bahan yang ada agar sesuai dengan strategi pembelajaran. Peran pengajar akan bertambah dalam menyampaikan pembelajaran beberapa bahan mungkin saja disampaikan tanpa bantuan pengajar, jika tidak ada, pengajar harus memberi penjelasan.

C) Pengajar tidak memakai bahan, tetapi menyampaikan semua pembelajaran menurut strategi pembelajaran nya yang telah disusunnya. Pengajar menggunakan strategi pembelajaran nya sebagai pedoman termasuk latihan dan kegiatan kelompok.

\section{Merancang dan melaksanakan evaluasi formatif (design and conduct formative evaluation)}

Menurut Dick dan Carrey (1985), ada tiga fase pokok penilaian formatif yaitu;(1) Fase perorangan atau fase klinis. Pada fase ini perancang bekerja dengan siswa secara perseorangan untuk memperoleh data guna menyempurnakan bahan pembelajaran. Data yang dimaksud di sini biasanya kesalahan-kesalahan. (2) Fase kelompok kecil, yaitu sekelompok siswa yang terdiri atas delapan sampai sepuluh orang yang 


\section{Jurual Dirosah Islamigah}

Volume 4 Nomor 2 (2022) 226-249 P-ISSN 2656-839x E-ISSN 2716-4683 DOI: 10.17467/jdi.v4i2.909

merupakan wakil cerminan populasi sasaran mempelajari bahan secara mandiri, dan kemudian diuji untuk memperoleh data yang diperlukan. (3) Fase uji lapangan. Boleh diikuti oleh banyak siswa; sering 30 orang sudah mencukupi.

\section{Revisi pembelajaran (instruksional revitions)}

Dick and Carrey (1985) mengemukakan ada dua revisi yang perlu dipertimbangkan, yaitu (l) revisi terhadap isi atau substansi bahan pembelajaran agar lebih cermat sebagai alat belajar, (2) revisi terhadap cara-cara yang dipakai dalam menggunakan bahan pembelajaran. Untuk keperluan bahan pembelajaran ada empat macam keterangan pokok yang menjadi sumber dalam melakukan revisi, yaitu (l) ciri anak didik dan tingkah laku masukan; (2) tanggapan langsung terhadap pembelajaran termasuk tes sisipan; (3) hasil pembelajaran pascates; (4) jawaban terhadap kuesioner.

\section{Mendesain dan melaksanakan evaluasi sumatif (design and conduct summative evaluation)}

Dengan evaluasi sumatif dapat menentukan nilai dari suatu desain pembelajaran dengan penilaian berdasarkan pada keefektifan dan efisiensi kegiatan belajar mengajar. Apabila semua tujuan sudah dapat tercapai, efektifitas pelaksanaan kegiatan pembelajaran dalam mata pelajaran dalam mata pelajaran tertentu dianggap berhasil dengan baik.

\section{c. Tujuan Pendidikan Agama Islam dan Budi Pekerti}

Tujuan pendidikan merupakan hal yang dominan dalam pendidikan sebagaimana yang diungkapkan oleh Abdul Majid yang dikutip dari pendapat Breiter, bahwa "pendidikan adalah persoalan tujuan dan focus. Mendidik anak berarti bertindak dengan tujuan agar mempengaruhi perkembangan anak sebagai seseorang secara utuh. ${ }^{13}$

Pendidikan Agama Islam bertujuan untuk meningkatkan keimanan, pemahaman, penghanyatan, dan pengalaman siswa tentang agama Islam sehingga menjadi manusia muslim yang beriman dan bertakwa kepada Allah SWT serta berakhlak mulia dalam kehidupan pribadi, bermasyarakat dan beragama. ${ }^{14}$

Zakiah Darajat membagi tujuan Pendidikan Agama Islam menjadi 4 (empat) macam, yaitu :15

1) Tujuan umum. Tujuan umum adalah tujuan yang akan dicapai dengan semua kegiatan pendidikan, baik dengan pengajaran atau dengan cara lain.

2) Tujuan akhir. Tujuan akhir adalah tercapainya wujud kamil, yaitu orang yang telah mencapai ketakwaan dan menghadap Allah dalam ketakwaannya.

13 Abdul Majid dan Dian Andayani, Pendidikan Agama Islam Berbasis Kompetensi, (Bandung: Remaja Rosdakarya, 2006), cet. Ke-3, 136.

${ }^{14}$ Alisuf Sabri, Ilmu Pendidikan, (Jakarta: CV. Pedoman Ilmu Jaya, 1999), Cet ke-1, 74-75.

15 Armai Arief, Pengantar Ilmu dan Metodologi Pendidikan Islam, (Jakarta: Ciputat Press, 2002), Cet ke-1, 19. 


\section{Jurual Dirosah Islamigah}

Volume 4 Nomor 2 (2022) 226-249 P-ISSN 2656-839x E-ISSN 2716-4683 DOI: 10.17467/jdi.v4i2.909

3) Tujuan sementara. Tujuan sementara adalah tujuan yang akan dicapai setelah anak diberi sejumlah pengalaman tertentu yang direncanakan dalam suatu kurikulum pendidikan formal.

Jadi Pendidikan Agama Islam disekolah/Madrasah bertujuan untuk menumbuhkan dan meningkatkan keimanan melalui pemberian dan pemupukan pengetahuan, penghayatan, serta pengalaman peserta didik tentang Agama Islam sehingga menjadi manusia muslim yang terus berkembang dalam hal keimanan, ketakwaan, berbangsa dan bernegara serta untuk dapat melanjutkan pada jenjang pendidikan yang lebih tinggi. ${ }^{16}$

\section{d. Identifikasi Karakter Peserta Didik/Siswa}

Karakteristik siswa adalah kualitas perseorangan siswa, seperti bakat, kemampuan awal yang dimiliki, motivasi belajar, dan kemungkinan hasil belajar yang akan dicapai. Karakteristik siswa akan mempengaruhi strategi pengelolaan pembelajaran. Pada tingkat tertentu, suatu kondisi pembelajaran akan mempengaruhi setiap komponen pemilihan metode pembelajaran. Demikian juga karakteristik siswa dapat mempengaruhi pemilihan strategi pengorganisasian isi dan strategi penyampaian pembelajaran PAI. Pembelajaran menempatkan siswa sebagai subjek. Guru perlu memahami karakteristik siswa agar pembelajaran mendapat hasil yang optimal.

Menurut Piaget, sebagaimana yang dikutip oleh Hamzah B. Uno, sejak lahir siswa mengalami tahap-tahap perkembangan kognitif. Setiap tahapan perkembangan kognitif tersebut mempunyai karakteristik yang berbeda, dijelaskan sebagai berikut:

1) Tahap sensorimotor (usia 0-2 tahun). Pada tahap ini siswa belum mengenal bahasa, belum memiliki pikiran pada masa-masa awal, dan belum mampu memahami realitas objektif.

2) Tahap pra-operasional (usia 2-7 tahun). Pada tahap ini kemampuan skema kognitifnya masih terbatas. Peserta didik suka meniru perilaku orang lain. Peserta didik mulai mampu menggunakan kata-kata yang benar dan mengekspresikan kalimat-kalimat pendek secara efektif.

3) Tahap operasional konkret (usia 7-11 tahun). Pada tahap ini peserta didik sudah mulai memahami aspek-aspek kumulatif materi, misalnya volume dan jumlah, serta sudah mampu berpikir sistematis mengenai benda-benda dan peristiwa yang konkret.

4) Tahap operasional formal (usia 11-15 tahun). Pada tahap ini peserta didik sudah menginjak usia remaja. Peserta didik mampu memecahkan masalah dengan menggunakan anggapan dasar yang relevan dengan lingkungan yang ia respon. ${ }^{17}$

\footnotetext{
${ }^{16}$ Abdul Majid dan Dian Andayani, Pendidikan Agama Islam Berbasis Kompetensi, 135.

${ }^{17}$ Paul Suparno, Teori Perkembangan Kognitif Jean Pieget, (Yogyakarta: Kanisius, 2001),
} 25. 


\section{Jurual Dirosah Islamigah}

Volume 4 Nomor 2 (2022) 226-249 P-ISSN 2656-839x E-ISSN 2716-4683 DOI: $10.17467 /$ jdi.v4i2.909

Siswa pada jenjang Sekolah Menengah berada pada tahap perkembangan usia remaja yang pada umumnya berusia antara 12-18 tahun. Peserta didik pada masa ini memiliki ciri-ciri individu yang kreatif. Ciri-ciri individu yang kreatif antara lain memiliki rasa ingin tahu yang besar, senang bertanya, imajinasi yang tinggi, minat yang luas, tidak takut salah, berani menghadapi risiko, bebas dalam berpikir, senang akan hal- hal yang baru, dan sebagainya. ${ }^{18}$ Beberapa komponen yang dapat dianalisis dalam kegiatan menganalisis karakteristik awal siswa meliputi: pengalaman siswa, pengetahuan siswa, kegemaran siswa, kondisi fisik siswa, lingkungan keluarga siswa, lingkungan sosial, dan status sosial siswa.

\section{e. Model Desain Pembelajaran Pendidikan Agama Islam}

Berkaitan dengan aspek-aspek atau komponen-komponen pembelajaran dan sistematika pembelajaran, terdapat sejumlah model-model sebagaimana dikemukakan para ahli. Berikut ini beberapa model yang dapat dijadikan acuhan :

1) Desain Pembelajaran Model Kemp

Model desain sistem instruksional yang dikembangkan oleh Kemp merupakan model yang membentuk siklus. Menurut Kemp pengembangan desain sistem pembelajaran terdiri atas komponen-komponen, yang dikembangkan sesuai dengan kebutuhan, tujuan dan berbagai kendala yang timbul.

Model sistem instruksional yang dikembangkan Kemp ini tidak ditentukan dari komponen mana seharusnya guru memulai proses pengembangan. Mengembangkan sistem instruksional, menurut Kemp dari mana saja bisa, asal saja urutan komponen tidak diubah, dan setiap komponen itu memerlukan revisi untuk mencapai hasil yang maksimal. Oleh karena itu model Kemp, dilihat dari kerangka sistem merupakan model yang sangat luwes.

Komponen-komponen dalam suatu desain instruksional menurut Kemp adalah:

a) hasil yang ingin dicapai;

b) analisis tes mata pelajaran;

c) tujuan khusus belajar;

d) aktivitas belajar;

e) sumber belajar;

f) layanan pendukung

g) Evaluasi belajar;

h) tes awal;

i) karakteristik belajar.

2) Model Banathy

Model desain sistem pembelajaran dari Banathy berbeda dengan model Kemp. Model ini memandang bahwa penyusunan sistem instruksional dilakukan melalui tahapan-tahapan yang jelas.

Terdapat 6 tahap dalam mendesain suatu program pembelajaran yakni:

${ }^{18}$ Paul Suparno, Teori Perkembangan Kognitif Jean Pieget, 26. 


\section{Jurual Dirosah Islamigah}

Volume 4 Nomor 2 (2022) 226-249 P-ISSN 2656-839x E-ISSN 2716-4683 DOI: $10.17467 /$ jdi.v4i2.909

a) Menganalisis dan merumuskan tujuan, baik tujuan pengembangan sistem maupun tujuan spesifik. Tujuan merupakan sasaran dan arah yang harus dicapai oleh siswa atau peserta didik.

b) Merumuskan kriteria tes yang sesuai dengan tujuan yang hendak dicapai. Item tes dalam tahap ini dirumuskan untuk menilai perumusan tujuan. Melalui rumusan tes dapat meyakinkan kita bahwa setiap tujuan ada alat untuk menilai keberhasilannya.

c) Menganalisis dan merumuskan kegiatan belajar, yakni kegiatan mengiventarisasi seluruh kegiatan belajar mengajar, menilai kemampuan penerapannya sesuai dengan kondisi yang ada serta menentukan kegiatan yang mungkin dapat diterapkan.

d) Merancang sistem, yaitu kegiatan menganalisis sistem menganalisis setiap komponen sistem, mendistribusikan dan mengatur penjadwalan.

e) Mengimplementasikan dan melakukan kontrol kualitas sistem, yakni melatih sekaligus menilai efektivitas sistem, melakukan penempatan dan melaksanakan evaluasi.

f) Mengadakan perbaikan dan perubahan berdasarkan hasil evaluasi.

3. Model PPSI (Prosedur Pengembangan Sistem Instruksional)

Model PPSI (Prosedur Pengembangan Sistem Instruksional) adalah model yang dikembangkan di Indonesia untuk mendukung pelaksanaan kurikulum 1975. PPSI berfungsi untuk mengefektifkan perencanaan dan pelaksanaan program pengajaran secara sistematis, untuk pedoman bagi guru dalam melaksanakan proses belajar mengajar. PPSI terdiri dari 5 tahap yakni:

a) Merumuskan tujuan, yakni kemampuan yang harus a capai oleh siswa. Ada 4 syarat dalam perumusan tujuan ini yakni tujuan harus operasional, artinya tujuan yang dirumuskan harus spesifik atau dapat diukur, berbentuk hasil belajar bukan proses belajar, berbentuk perubahan tingkah laku dan dalam setiap rumusan tujuan hanya satu bentuk tingkah laku.

b) Mengembangkan alat evaluasi, yakni menentukan jenis tes dan menyusun item soal untuk masing-masing tujuan. Alat evaluasi disimpan pada tahap 2 setelah perumusan tujuan untuk meyakinkan ketepatan tujuan sesuai dengan kriteria yang telah ditentukan.

c) Mengembangkan kegiatan belajar mengajar, yakni merumuskan semua kemungkinan kegiatan belajar dan menyeleksi kegiatan belajar perlu ditempuh.

d) Mengembangkan program kegiatan pembelajaran yakni merumuskan materi pelajaran, menetapkan metode dan memilih alat dan sumber pelajaran

e) Pelaksanaan program, yaitu kegiatan mengadakan prates, menyampaikan materi pelajaran, mengadakan psikotes, dan melakukan perbaikan. 


\section{Jurual Dirosah Islamigah}

Volume 4 Nomor 2 (2022) 226-249 P-ISSN 2656-839x E-ISSN 2716-4683 DOI: $10.17467 /$ jdi.v4i2.909

\section{Model Pengembangan Pembelajaran Menurut Dick \& Carey}

Perancangan pengajaran menurut sistem pendekatan model Dick \& Carey, dikembangkan oleh Walter Dick \& Lou Carey (1990). Menurut pendekatan ini terdapat beberapa komponen yang akan dilewati di dalam proses pengembangan dan perancangan tersebut: 19

a) Identifikasi tujuan pembelajaran (identity instructional goals)

b) Melakukan analisis instruksional (conducting a goal analysis)

c) Mengidentifikasi tingkah laku/karakteristik siswa (identity entry behaviour, characteristics)

d) Merumuskan tujuan kinerja (write performance objective)

e) Pengembangan tes acuan patokan (develop criterian referenced test items)

f) Pengembangan strategi pengajaran (develop instructional strategi)

g) Pengembangan atau memilih pengajaran (develop and select instructional materialis)

h) Merancang dan melaksanakan evaluasi formatif (design and conduct formative evaluation)

i) Menulis perangkat (design and conduct summative evaluation)

j) Revisi pengajaran (instruksional revitions)

\section{Model ASSURE}

Sharon E Smaldino, James D. Russel, Robert Heinich, dan Michael Molenda (2005) mengemukakan sebuah model desain sistem pembelajaran yang diberi nama ASSURE. Sama sepert model desain sistem pembelajaran yang lain, model ini dikembangkan untuk menciptakan aktivitas pembelajaran efisien dan efektif, khususnya pada kegiatan yang menggunakan media dan teknologi.

Langkah-langkah penting yang perlu dilakukan dalam model desain sistem pembelajaran ASSURE meliputi beberapa aktivitas, yaitu:

a) Analyze learners :melakukan analisis karakteristik siswa

b) State objectives : menetapkan tujuan pembelajaran,

c) Select methods media, and materials :memilih media, metode pembelajaran, dan bahan ajar

d) Utilize materials :memanfaatkan bahan ajar

e) Require learners participation :melibatkan siswa dalam kegiatan pembelajaran, dan

f) Evaluate and revise : mengevaluasi dan merevisi program pembelajaran

6. Model smith dan ragan

Patricia L. Smith dan Tillman J. Ragan (2003) mengemukakan sebuah model desain sistem pembelajaran yang populer di kalangan mahasiswa dan profesional yang memiliki kecenderungan terhadap implementasi teori belajar kognitif. Hampir semua langkah dan prosedur dalam model desain sistem pembelajaran ini difokuskan

19 Zaenal Arifin Ahmad, Perencanaan Pembelajaran dari Desain sampain implementasi, PT.Pustaka Insan Madani, Yogyakarta, 2012, 65-66. 


\section{Jurual Dirosah Islamigah}

Volume 4 Nomor 2 (2022) 226-249 P-ISSN 2656-839x E-ISSN 2716-4683 DOI: $10.17467 /$ jdi.v4i2.909

pada rancangan tentang strategi pembelajaran. Model desain sistem pembelajaran yang dikemukakan oleh Smith dan Ragan terdiri atas beberapa langkah dan prosedur pokok sebagai berikut.

a) Analisis lingkungan belajar

b) Analisis karakteristi siswa

c) Analisis tugas pembelajaran

d) Menulis butir tes

e) Menentukan strategi pembelajaran

f) Memproduksi program pembelajaran

g) Melaksanakan evaluasi formatif

h) Merevisi program pembelajaran.

\section{Model ADDIE}

Salah satu model desain sistem pembelajaran yang memperlihatkan tahapantahapan dasar desain sistem pembelajaran yang sederhana dan mudah dipelajari adalah model ADDIE. Model ini, sesuai dengan namanya, terdiri dari lima fase atau tahap utama, yaitu (Analysis, Design, Development, Implementation, and Evaluation).

\section{f. Desain Pembelajaran PAI di Sekolah Menengah}

Implementasi Undang-undang Nomor 22 tahun 2003 tentang Sistem Pendidikan Nasional dijabarkan ke dalam sejumlah peraturan antara lain Peraturan Pemerintah Nomor 32 tahun 2013 tentang Standar Pendidikan Nasional. Peraturan Pemerintah ini memberikan arahan tentang perlunya disusun dan dilaksanakan delapan standar nasional pendidikan, yaitu standar isi, standar proses, standar kompetensi lulusan, standar pendidik dan tenaga kependidikan, standar sarana dan prasarana, standar pengelolaan, standar pembiayaan, dan standar penilaian pendidikan.

a. Standar kompetensi lulusan (SKL) mata pelajaran PAI di S

Standar kompetensi lulusan (SKL) mata pelajaran PAI di SMA sebagai berikut:

a) Memahami ayat-ayat al-Qur'an yang berkaitan dengan fungsi manusia sebagai khalifah, demokrasi, serta pengembangan ilmu pengetahuan dan teknologi.

b) Meningkatkan keimanan kepada Allah swt., sampai keimanan kepada qadha dan qhadar melalui pemahaman terhadap sifat asmaul husna.

c) Berperilaku terpuji seperti husnudhzon, taubat dan roja, dan meninggalkan perilaku tercela, seperti isyrof, tabzir, dan fitnah.

d) Memahami sumber hukum Islam dan hukum taklifi serta menjelaskan hukum muamalah dan hukum keluarga dalam Islam.

e) Memahami sejarah Nabi Muhammad saw., pada periode Mekkah dan Madinah serta perkembangan Islam di Indonesia dan di dunia. ${ }^{20}$

2) Standar Isi (standar kompetensi dan kompetensi dasar) PAI di SMA

${ }^{20}$ Afnil Guza, Standar Nasional, (Jakarta: Asa Mandiri, 2008), 160. 


\section{Jurual Dirosah Islamigah}

Volume 4 Nomor 2 (2022) 226-249 P-ISSN 2656-839x E-ISSN 2716-4683 DOI: 10.17467/jdi.v4i2.909

PAI merupakan salah satu pelajaran wajib yang harus diajarkan di setiap jalur, jenis, dan jenjang pendidikan nasional, tidak terkecuali di SMA, baik negeri maupun swasta. Peraturan Menteri Pendidikan Nasional (Permendiknas) Nomor 22 tahun 2006 tentang standar isi menjelaskan bahwa PAI di SMA/MA bertujuan untuk:

a) Menumbuh kembangkan akidah melalui pemberian, pemupukan, dan pengembangan pengetahuan, penghayatan, pengamalan, pembiasaan, serta pengamalan peserta didik tentang agama Islam sehingga menjadi manusia muslim yang terus berkembang keimanan dan ketakwaannya kepada Allah swt.

b) Mewujudkan manusia Indonesia yang taat beragama dan berakhlak mulia yaitu manusia yang berpengetahuan, rajin beribadah, cerdas, produktif, adil, jujur, etis, berdisiplin, bertoleransi (tasamuh), menjaga keharmonisan secara personal dan sosial serta mengembangkan budaya agama dalam komunitas sekolah. ${ }^{21}$

c) Standar isi adalah ruang lingkup materi dan tingkat kompetensi yang dituangkan dalam kriteria tentang kompetensi tamatan, kompetensi bahan kajian, kompetensi mata pelajaran, dan silabus pembelajaran yang harus dipenuhi oleh peserta didik. ${ }^{46}$ Standar isi terdiri atas standar kompetensi dan kompetensi dasar mata pelajaran PAI di SMA dimuat dalam lampiran.

3) Materi PAI dan Budi Pekerti di Sekolah Menengah Atas

Bahan pengajaran PAI meliputi 7 unsur pokok, yaitu: unsur keimanan, unsur ibadah, unsur al-Qur'an, unsur akhlak, unsur syari'ah, unsur muamalah, dan unsur tarikh, atau 5 unsur pokok yaitu al-Qur'an, keimanan, akhlak, fiqih dan bimbingan ibadah, dan tarikh, semuanya mengandung konsekuensi bahwa PAI harus mengembangkan dan mewujudkan tiga aspek pendidikan secara tuntas pada diri siswa, yaitu kognitif, afektif, dan psikomotorik. Dengan demikian, siswa dapat mengamalkan nilai-nilai agama dalam kehidupan sehari-hari dan di sekolah pun mereka mendapat nilai yang bagus.

4) Metode Pembelajaran PAI dan Budi Pekerti di Sekolah Menengah

Metode pengajaran PAI sangat bermanfaat bagi calon guru/ pendidik agama, karena:

a. Membahas tentang berbagai prinsip, teknik-teknik, dan pendekatan pengajaran yang digunakan. Dengan mempelajarinya seorang guru dapat memilih metode manakah yang layak dipakai, mempertimbangkan keunggulan dan kelemahannya, serta kesesuaian metode tersebut dengan karakteristik siswa dan ciri-ciri khas materi yang akan disajikan sehingga kegiatan belajar mengajar dapat berlangsung secara optimal untuk mencapai tujuan yang ditetapkan;

${ }^{21}$ Permendiknas Nomor 22 tahun 2006, tentang Standar Isi dan Kompetensi Dasar Tingkat SMA-MA-SMK-MAK, (Jakarta: Sinar Grafika, 2006), h. 81. 


\section{Jurval Dirosah Islamiyah}

Volume 4 Nomor 2 (2022) 226-249 P-ISSN 2656-839x E-ISSN 2716-4683 DOI: $10.17467 /$ jdi.v4i2.909

b. Terlalu luasnya materi agama dan sedikitnya waktu yang tersedia untuk menyampaikan bahan, sudah barang tentu memerlukan pemikiran yang mendalam bagaimana usaha guru agama, agar tujuan pengajaran dan pendidikan agama dapat tercapai dengan sebaik-sebaiknya. Di sinilah fungsi metode pengajaran agama dapat memberi makna yang besar sekali terhadap guru yang telah mempelajarinya secara baik, terutama yang berkenaan dengan desain dan rancangan pengajaran.

c. Sifat pengajaran agama lebih banyak menekankan pada segi tujuan afektif (sikap) dibanding tujuan kognitif, menjadikan peranan guru agama lebih bersifat mendidik daripada mengajar. Metode pengajaran agama turut memberikan distribusi pengetahuan terhadap siswa. ${ }^{22}$

\section{Pelaksanaan Pembelajaran Pendidikan Agama Islam dan Budi Pekerti}

Pelaksanaan pembelajaran memiliki beberapa persyaratan sebagai berikut: (1) Alokasi waktu jam tatap muka pembelajaran, yaitu: SD/MI: 35 menit, SMP/MTs: 40 menit, SMA/MA: 45 menit, dan SMK/MAK: 45 menit; (2) Rombongan Belajar, seperti tersaji dalam tabel 2.5; (3) Buku teks pelajaran, jumlahnya disesuaikan dengan kebutuhan peserta didik; dan (4) Pengelolaan Kelas dan laboratorium. ${ }^{23}$

Tabel 2.4 Rombongan Belajar

\begin{tabular}{|c|l|c|c|}
\hline No & $\begin{array}{c}\text { Satuan } \\
\text { Pendidikan }\end{array}$ & $\begin{array}{c}\text { Jumlah Rombongan } \\
\text { Belajar }\end{array}$ & $\begin{array}{c}\text { Jumlah Maksimum } \\
\text { Peserta Didik Per } \\
\text { Rombongan Belajar }\end{array}$ \\
\hline 1. & SD/MI & $6-24$ & 28 \\
\hline 2. & SMP/Mts & $3-33$ & 32 \\
\hline 3. & SMA/MA & $3-36$ & 36 \\
\hline 4. & SMK & $3-72$ & 36 \\
\hline 5. & SDLB & 6 & 5 \\
\hline 6. & SMPLB & 3 & 8 \\
\hline 7. & SMALB & 3 & 8 \\
\hline
\end{tabular}

Pelaksanaan pembelajaran merupakan implementasi dari RPP, pelaksanaan pembelajaran meliputi tiga tahapan kegiatan sebagai berikut:24

a. Kegiatan Pendahuluan

1) Menyiapkan peserta didik secara psikis dan fisik untuk mengikuti proses

22 Basyiruddin Usman, Metodologi Pembelajaran Agama Islam, (Jakarta: Ciputat Pers, 2002), 6 .

${ }^{23}$ Lampiran Permendikbud No. 22/2016, 9-10.

${ }^{24}$ Peraturan Menteri Pendidikan Nasional Republik Indonesia No. 41 Tahun 2007 tentang Standar Proses Untuk Satuan Pendidikan Dasar dan Menengah Badan Standar Pendidikan, 2007. 


\section{Jurual Dirosah Islamigah}

Volume 4 Nomor 2 (2022) 226-249 P-ISSN 2656-839x E-ISSN 2716-4683 DOI: $10.17467 /$ jdi.v4i2.909

pembelajaran.

2) Mengajukan pertanyaan-pertanyaan yang mengaitkan pengetahuan yang sebelumnya dengan materi yang akan dipelajari.

3) Menjelaskan tujuan pembelajaran atau kompetensi dasar yang akan dicapai.

4) Menyampaikan cakupan materi dan penjelasan uraian kegiatan sesuai silabus.

b. Kegiatan Inti

Kegiatan inti menggunakan metode yang disesuaikan dengan karakteristik peserta didik dan mata pelajaran yang meliputi;

1) Eksplorasi, dalam kegiatan ini guru memfasilitasi agar terjadi interaksi antar peserta didik serta antara peserta didik dengan guru, lingkungan, dan sumber belajar lainnya.

2) Elaborasi, dalam kegiatan ini guru memberi kesempatan untuk berfikir, menganalisis, menyelesaikan masalah, dan melakukan sesuatu untuk belajar.

3) Konfirmasi, dalam kegiatan ini guru memberikan konfirmasi terhadap hasil eksplorasi dan elaborasi peserta didik melalui berbagai sumber. ${ }^{25}$

Kegiatan inti pada kurikulum 2013 proses pembelajaran menggunakan pendekatan scientific, kegiatan ini meliputi;

1) Mengamati, dalam kegiatan ini peserta didik melihat, membaca, mendengar, memperhatikan tayangan dan penjelasan guru tentang materi ajar.

2) Menanya, dalam kegiatan ini peserta didik menanya, memberi umpan balik, mengungkapkan sesuatu. Dialog mendalam secara klasikal yang berhubungan dengan materi ajar.

3) Eksplorasi, dalam kegiatan ini peserta didik dikondisikan untuk berpikir kritis, mendialogkan, mengeksperimen dan melakukan diskusi kelompok.

4) Mengasosiasi, kegiatan ini peserta didik menghubungkan materi lain dan membuat rumusan dengan melakukan analisis terhadap materi pembelajaran.

5) Mengkomunikasi, kegiatan ini peserta didik mempresentasikan, mendialogkan, menyimpulkan dari hasil diskusi atau membuat kesimpulan terhadap materi pembelajaran. ${ }^{26}$

Kegiatan inti pada kurikulum 2013 berbeda dengan kurikulum sebelumnya. Pada kurikulum KTSP pelaksanaan pembelajaran biasanya masih berpusat pada guru, sedangkan kurikulum 2013 menggunakan pendekatan scientific dan pelaksanaan pembelajarannya berpusat pada peserta didik. Tugas guru dalam pembelajaran adalah sebagai moderator dan fasilitator yang mengkondisikan peserta didik untuk melakukan kegiatan belajar.

c. Kegiatan Penutup

Kegiatan penutup merupakan kegiatan akhir pada proses pembelajaran.

\footnotetext{
${ }^{25}$ Ramayulis, Profesi dan Etika Keguruan, 177-178.

${ }^{26}$ Nasir A. Baki, Metode Pembelajaran Agama Islam, 223-224.
} 


\section{Jurual Dirosah Islamigah}

Volume 4 Nomor 2 (2022) 226-249 P-ISSN 2656-839x E-ISSN 2716-4683 DOI: 10.17467/jdi.v4i2.909

Kegiatan ini meliputi: ${ }^{27}$

1) Guru bersama peserta didik membuat kesimpulan.

2) Melakukan penilaian/refleksi terhadap kegiatan yang sudah dilaksanakan secara konsisten dan terprogram.

3) Memberikan umpan balik terhadap proses dan hasil pembelajaran.

4) Merencanakan kegiatan tindak lanjut dalam bentuk pembelajaran ramedial, program pengayaan, layanan konseling dan atau memberikan tugas individual maupun kelompok sesuai dengan hasil belajar peserta didik.

5) Menyampaikan rencana pembelajaran pada pertemuan berikutnya.

Menurut kurikulum 2013 pelaksanaan pembelajaran PAI di tingkat Sekolah menengah diajarkan secara komprehensif antara sikap, pengetahuan, dan keterampilan. Pemilihan sumber belajar mengacu pada perumusan yang ada dalam silabus yang dikembangkan. Sumber belajar mencakup sumber rujukan, lingkungan, media, narasumber, alat dan bahan. Sumber belajar dituliskan secara lebih operasional, dan langsung dinyatakan bahan ajar apa yang digunakan. ${ }^{28}$ Misalnya menggunakan buku maka ditulis identitas referensi dari buku tersebut. Sebaiknya guru membuat RPP dengan baik agar pelaksanaan dalam pembelajaran juga berjalan dengan maksimal.

\section{Evaluasi Pembelajaran Pendidikan Agama Islam dan Budi Pekerti}

\section{a. Pengertian Evaluasi}

Rangkaian akhir dari komponen dalam suatu system pendidikan yang penting, adalah penilaian (evaluasi). Berhasil atu gagalnya suatu pendidikan dalam mencapai tujuannya dapat dilihat setelah dilakukan penilaian terhadap produk yang dihasilkannya.

Tugas guru setelah melaksanakan pembelajaran adalah melakukan evaluasi hasil pembelajaran. Sebelum dipaparkan mengenai pengertian evaluasi. Biasanya dikenal juga tentang istilah penilaian. Penilaian dan evaluasi mempunyai istilah yang hampir serupa namun tidak sama.

Penilaian (assessment) diartikan sebagai serangkaian kegiatan untuk memperoleh, menganalisis, dan menafsirkan data tentang proses dan hasil belajar siswa dalam tingkat kelas yang dilakukan secara sistematis dan berkesinambungan, sehingga menjadi informasi yang bermakna dalam pengambilan keputusan. ${ }^{29}$

Abdul Majid mengartikan penilaian sebagai kegiatan yang dilakukan untuk memperoleh dan mengefektifkan informasi tentang hasil belajar siswa pada tingkat kelas selama dan setelah kegiatan belajar mengajar. ${ }^{30}$

\footnotetext{
${ }^{27}$ Peraturan Menteri Pendidikan Nasional Republik Indonesia No. 41 Tahun 2007 tentang Standar Proses Untuk Satuan Pendidikan Dasar dan Menengah Badan Standar Pendidikan, 2007.

${ }^{28}$ Nasir A. Baki, Metode Pembelajaran Agama Islam, 260-261

${ }^{29}$ Ramayulis, Profesi dan Etika Keguruan, 293. Guru, 185 .

30 Abdul Majid, Perencanaan Pembelajaran: Mengembangkan Strandar Kompetensi
} 


\section{Jurual Dirosah Islamigah}

Volume 4 Nomor 2 (2022) 226-249 P-ISSN 2656-839x E-ISSN 2716-4683 DOI: $10.17467 /$ jdi.v4i2.909

Zainal Arifin mengemukakan penilaian adalah suatu kegiatan untuk memberikan berbagai informasi secara berkesinambungan dan menyeluruh tentang proses dan hasil yang telah dicapai siswa. ${ }^{31}$

Berdasarkan pengertian tersebut, penilaian merupakan suatu proses kegiatan yang sistematis dan berkesinambungan untuk memperoleh informasi dalam rangka membuat hasil keputusan tentang hasil belajar peserta didik. Jadi komponen dalam penilaian adalah peserta didik tanpa menyinggung komponen pembelajaran yang lain.

Istilah evaluasi secara etimologis berasal dari bahasa Inggris "evaluation" yang berarti penilaian terhadap sesuatu. ${ }^{32}$ Evaluasi mempunyai ruang lingkup yang lebih luas daripada penilaian, sedangkan penilaian lebih terfokus pada aspek tertentu saja yang merupakan bagian dari ruang lingkup tersebut. ${ }^{33}$ Jika yang ingin dinilai adalah sistem pembelajaran, maka ruang lingkupnya adalah semua komponen pembelajaran, dan istilah yang tepat untuk menilai sistem pembelajaran adalah evaluasi, bukan penilaian. Jika hal yang ingin dinilai satu atau beberapa bagian atau komponen pembelajaran, misalnya hasil belajar, maka istilah yang tepat digunakan adalah penilaian, bukan evaluasi.

Evaluasi mengandung tiga makna, yaitu pengukuran, penilaian, dan evaluasi. $^{34}$ Ketiga istilah tersebut hampir sama namun mempunyai makna yang berbeda, meskipun dalam prakteknya istilah tersebut saling terkait. Pengukuran adalah suatu proses atau kegiatan untuk menentukan kuantitas sesuatu. Sedangkan penilaian diartikan sebagai serangkaian kegiatan untuk menafsirkan data tentang proses dan hasil belajar siswa untuk mencari informasi dalam pengambilan keputusan. Evaluasi dapat diartikan sebagai kegiatan yang dilakukan untuk mengetahui perubahan atau perkembangan hasil belajar peserta didik setelah ditetapkan. Kegiatan dalam evaluasi pada umumnya diawali dengan dengan kegiatan pengukuran dan penilaian.

Berdasarkan uraian tersebut, evaluasi dapat dipahami sebagai suatu kegiatan untuk mengetahui perkembangan peserta didik dari sistem pembelajaran sesuai tujuan. Selanjutnya istilah yang digunakan dalam pembahasan ini yakni evaluasi bukan penilaian maupun pengukuran. Evaluasi yang dimaksud yakni evaluasi dalam pendidikan, yaitu Pendidikan Agama Islam. Sasaran yang akan dievaluasi yaitu tentang akhlak, sehingga akan disoroti tentang sistem pembelajaran agama Islam dalam pembinaan akhlak peserta didik.

Tugas pendidikan Islam termasuk tugas guru PendidikanAgama Islam yang meletakkan faktor fitrah anak, nilai-nilai agama dijadikan landasan kepribadian peserta didik yang dibentuk melalui proses pembelajaran. Oleh karena itu, identitas

${ }^{31}$ Zainal Arifin, Evalusasi Pembelajaran: Prinsip, Teknik, Prosedur (Cet. V; Bandung: PT. Remaja Rosdakarya, 2013), 4.

32 Ahmad Tafsir, Metodologi Pengajaran Agama Islam (Cet. XI; Bandung: PT. Remaja Rosdakarya, 2011), 40.

${ }^{33}$ Zainal Arifin, Evaluasi Pembelajaran: Prinsip, Teknik, Prosedur, 2.

${ }^{34}$ Ramayulis, Profesi dan Etika Keguruan, 291. 


\section{Jurual Dirosah Islamigah}

Volume 4 Nomor 2 (2022) 226-249 P-ISSN 2656-839x E-ISSN 2716-4683 DOI: $10.17467 /$ jdi.v4i2.909

Islam yang telah terbentuk dan menjiwai pribadi peserta didik tidak dapat diketahui oleh pendidik atau guru tanpa melalui evaluasi. Jadi evaluasi mempunyai kedudukan yang sangat penting untuk mengetahui hasil pembelajaran yang telah dilakukan.

\section{b. Tujuan Evaluasi}

Secara umum tujuan evaluasi adalah untuk menentukan kualitas sesuatu, terutama yang berkenaan dengan nilai dan arti. ${ }^{35}$ Seorang guru jika ingin melakukan kegiatan evaluasi, maka harus mengetahui dan memahami terlebih dahulu tentang tujuan dan fungsi evaluasi. Tujuan evaluasi pembelajaran adalah untuk mengetahui keefektifan dan efisiensi sistem pembelajaran, baik yang menyangkut tentang tujuan, materi, metode, media, sumber belajar, lingkungan maupun sistem penilaian itu sendiri. Tujuan khusus evaluasi pembelajaran disesuaikan dengan jenis evaluasi pembelajaran itu sendiri, seperti evaluasi perencanaan dan pengembangan, evaluasi monitoring, evaluasi dampak, evaluasi efisiensi, ekonomis dan evaluasi program komprehensif. ${ }^{36}$

Evaluasi banyak digunakan dalam berbagai bidang dan kegiatan, antara lain dalam kegiatan bimbingan dan penyuluhan, supervisi, seleksi, dan pembelajaran. Setiap bidang atau kegiatan tersebut mempunyai tujuan yang berbeda. Dalam kegiatan bimbingan, tujuan evaluasi adalah untuk memperoleh informasi secara menyeluruh mengenai karakteristik peserta didik, sehingga dapat diberikan bimbingan dengan sebaik-baiknya. Begitu juga dalam kegiatan supervisi, tujuan evaluasi adalah untuk menentukan keadaan suatu situasi pendidikan atau pembelajaran, sehingga dapat diusahakan langkah-langkah perbaikan untuk meningkatkan mutu pendidikan di sekolah. Dalam kegiatan seleksi, tujuan evaluasi adalah untuk mengetahui tingkat pengetahuan, keterampilan, sikap dan nilai -nilai peserta didik untuk jenis pekerjaan, jabatan atau pendidikan tertentu. ${ }^{37}$

Tujuan evaluasi dalam pembahasan ini adalah untuk mengetahui sejauh mana pembinaan akhlak peserta didik dalam pelaksanaan pembelajaran pada mata pelajaran Pendidikan Agama Islam. Hal ini untuk mengetahui sikap atau akhlak peserta didik dalam pembelajaran agama di lingkungan sekolah umum yang latar belakang peserta didiknya berbeda-beda.

\section{c. Fungsi Evaluasi}

Upaya penerapan prinsip keadilan keikhlasan, maka evaluasi pendidikan berfungsi sebagai berikut:

1) Untuk mengetahui atau mengumpulkan informasi tentang taraf perkembangan dan kemajuan yang diperoleh peserta didik dalam rangka mencapai tujuan yang telah ditetapkan dalam kurikulum pendidikan.

\footnotetext{
${ }^{35}$ Zainal Arifin, Evaluasi Pembelajaran: Prinsip, Teknik, Prosedur, 6.

${ }^{36}$ Zainal Arifin, Evaluasi Pembelajaran: Prinsip, Teknik, Prosedur, 14.

${ }^{37}$ Zainal Arifin, Evaluasi Pembelajaran: Prinsip, Teknik, Prosedur, 14.
} 


\section{Jurual Dirosah Islamigah}

Volume 4 Nomor 2 (2022) 226-249 P-ISSN 2656-839x E-ISSN 2716-4683 DOI: $10.17467 /$ jdi.v4i2.909

2) Untuk mengetahui prestasi hasil belajar guna menetapkan keputusan apakah bahan pelajaran perlu diulang atau dapat dilanjutkan.

3) Untuk mengetahui efektifitas cara belajar dan mengajar yang telah dilaku kan benar-benar tepat atau tidak, baik yang berkenaan dengan sikap guru maupun peserta didik.

4) Untuk mengetahui kelembagaan guna menetapkan keputusan yang tepat dan mewujudkan persaingan sehat, dalam rangka berpacu dalam prestasi.

5) Untuk mengetahui sejauh mana kurikulum telah dipenuhi dalam proses kegiatan belajar-mengajar.

6) Untuk mengetahui pembiayaan yang dibutuhkan dan yang dikeluarkan dalam kebutuhan fisik maupun dana yang dibutuhkan seperti: fasilitas ruangan, perpustakaan, honorarium guru dan lain-lain.

7) Sebagai bahan laporan terhadap orang tua peserta didik, berupa rapor, ijazah, piagam dan sebagainya. ${ }^{38}$

Berdasarkan uraian tersebut, kedudukan evaluasi dalam pembelajaran sangat penting. Hasil dari evaluasi ini akan menjadi pertimbangan dan perbaikan pembelajaran dan perkembangan belajar bagi peserta didik. Evaluasi berfungsi untuk menilai akhlak peserta didik setelah mendapatkan pembelajaran. Peserta didik diharapkan mampu memahami materi yang diajarkan sekaligus mampu menerapkan dalam kehidupan sehari-hari, baik di sekolah, di rumah maupun di masyarakat.

\section{d. Evaluasi/ Penilaian Proses dan Hasil Pembelajaran}

Penilaian adalah proses pengumpulan dan pengolahan informasi untuk mengukur pencapaian hasil belajar siswa. ${ }^{39}$ Penilaian hasil belajar oleh pendidik bertujuan untuk memantau dan mengevaluasi proses, kemajuan belajar, dan perbaikan hasil belajar peserta didik secara berkesinambungan. ${ }^{40}$

Dalam permendikbud No. 22 Tahun 2016 dijelaskan sebagai berikut:

Penilaian proses pembelajaran menggunakan pendekatan penilaian otentik yang menilai kesiapan peserta didik, proses, dan hasil belajar secara utuh. Keterpaduan penilaian ketiga komponen tersebut akan menggambarkan kapasitas, gaya, dan perolehan belajar peserta didik yang mampu menghasilkan dampak instruksional (instructional effect) pada aspek pengetahuan dan dampak pengiring (nurturant effect) pada aspek sikap. Hasil penilaian otentik digunakan guru untuk merencanakan program perbaikan (remedial) pembelajaran, pengayaan (enrichment), atau pelayanan konseling. Selain itu, hasil penilaian otentik digunakan sebagai bahan untuk memperbaiki proses pembelajaran sesuai dengan SNP. Evaluasi proses pembelajaran dilakukan saat proses pembelajaran dengan menggunakan alat:

\footnotetext{
${ }^{38}$ Ramayulis, Profesi dan Etika Keguruan, 294.

${ }^{39}$ Permendiknas No. 23/2016, Pasal 1 Ayat (2).

${ }^{40}$ Permendiknas No. 23/2016, Pasal 4 Ayat (1).
} 


\section{Jurval Dirosah Islamiyah}

Volume 4 Nomor 2 (2022) 226-249 P-ISSN 2656-839x E-ISSN 2716-4683 DOI: $10.17467 /$ jdi.v4i2.909

lembar pengamatan, angket sebaya, rekaman, catatan anekdot, dan refleksi. Evaluasi hasil pembelajaran dilakukan saat proses pembelajaran dan di akhir satuan pelajaran dengan menggunakan metode dan alat: tes lisan/perbuatan, dan tes tulis. Hasil evaluasi akhir diperoleh dari gabungan evaluasi proses dan evaluasi hasilpembelajaran. ${ }^{41}$

Kurikulum 2013 adalah kurikulum yang berbasis kompetensi yang menekankan pembelajaran berbasis aktivitas yang bertujuan memfasilitasi peserta didik memperoleh sikap, pengetahuan, dan keterampilan. ${ }^{42}$ Penilaian tersebut dijelaskan sebagai berikut:

\section{1) Penilaian Sikap}

Penilaian sikap adalah kegiatan untuk mengetahui kecenderungan perilaku spiritual dan social siswa dalam kehidupan rendah hingga tinggi. Penilaian pengetahuan, selain untuk mengetahui apakah siswa telah mencapai KBM/KKM, juga untuk mengidentifikasi kelemahan dan kekuatan penguasaan pengetahuan siswa dalam proses pembelajaran (diagnostic). Hasil penilaian digunakan memberi umpan balik (feedback) kepada siswa dan guru sehari-hari di dalam dan di luar kelas sebagai hasil pendidikan. Penilaian sikap ditujukan untuk mengetahui capaian/perkembangan sikap siswa dan memfasilitasi tumbuhnya perilaku siswa sesuai butir-butir nilai sikap dalam KD dari KI-1 dan KI-2.

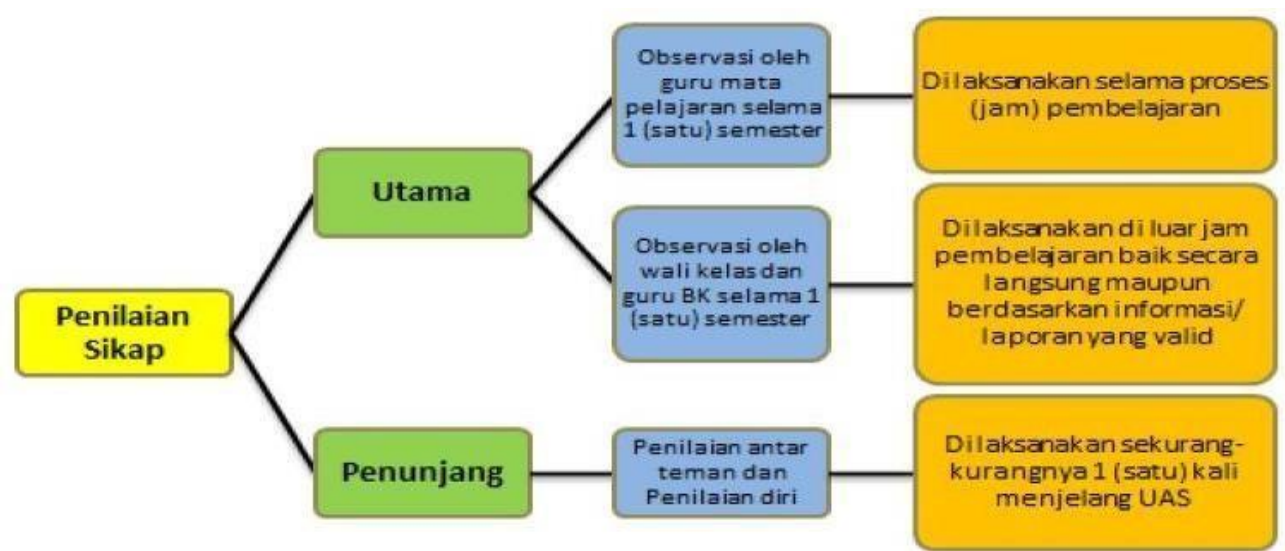

Gambar 2.3 Skema Penilaian Sikap

2) Penilaian Pengetahuan

Penilaian pengetahuan adalah penilaian yang dilakukan untuk mengetahui penguasaan siswa yang meliputi pengetahuan faktual, konseptual, maupun prosedural serta kecakapan berpikir tingkat untuk perbaikan mutu pembelajaran.

${ }^{41}$ Lampiran Permendikbud No.22/2016, 13.

42 Kemendikbud, Panduan Penilaian untuk Sekolah Menengah Pertama (SMP) (Jakarta: Dirjen Pendidikan Dasar dan Menengah, 2015), 5. 


\section{Jurual Dirosah Islamigah}

Volume 4 Nomor 2 (2022) 226-249 P-ISSN 2656-839x E-ISSN 2716-4683 DOI: $10.17467 /$ jdi.v4i2.909

Hasil penilaian pengetahuan yang dilakukan selama dan setelah proses pembelajarandinyatakan dalam bentuk angka dengan rentang 0-100.43

Penilaian kinerja, penilaian proyek, dan penilaian portofolio. Teknik penilaian keterampilan yang digunakan dipilih sesuai dengan karakteristik KD pada KI-4.44

Tabel 2.5

Teknik Penilaian Pengetahuan

\begin{tabular}{|l|l|l|}
\hline \multicolumn{1}{|c|}{ Teknik } & \multicolumn{1}{|c|}{ Bentuk Instrumen } & \multicolumn{1}{c|}{ Tujuan } \\
\hline Tes Tertulis & $\begin{array}{l}\text { Benar-Salah, Menjodohkan, } \\
\text { Pilihan Ganda, } \\
\text { Isian/Melengkapi, Uraian }\end{array}$ & $\begin{array}{l}\text { Mengetahui penguasaan } \\
\text { pengetahuan siswa untuk } \\
\text { perbaikan proses pembelajaran } \\
\text { dan/atau pengambilan nilai }\end{array}$ \\
\hline Tes Lisan & Tanya jawab & $\begin{array}{l}\text { Mengecek pemahaman siswa } \\
\text { untuk perbaikan proses } \\
\text { pembelajaran }\end{array}$ \\
\hline Penugasan & $\begin{array}{l}\text { Tugas yang dilakukan secara } \\
\text { individu maupun kelompok }\end{array}$ & $\begin{array}{l}\text { Memfasilitasi penguasaan } \\
\text { pengetahuan (bila diberikan } \\
\text { selama proses pembelajaran) } \\
\text { atau mengetahui penguasaan } \\
\text { pengetahuan (bila diberikan } \\
\text { pada akhir pembelajaran) }\end{array}$ \\
\hline Portofolio & $\begin{array}{l}\text { Sampel pekerjaan siswa } \\
\text { terbaik yang diperoleh dari } \\
\text { penugasan dan tes tertulis }\end{array}$ & $\begin{array}{l}\text { Sebagai (sebagian) bahan guru } \\
\text { mendeskripsikan capaian } \\
\text { pengetahuan di akhir semester }\end{array}$ \\
\hline
\end{tabular}

1) Penilaian Keterampilan

Penilaian keterampilan adalah penilaian yang dilakukan untuk mengetahui kemampuan siswa dalam menerapkan pengetahuan untuk melakukan tugas tertentu di dalam berbagai macam konteks sesuai dengan indikator pencapaian kompetensi. Penilaian keterampilan dapat dilakukan dengan berbagai teknik, antara lain :

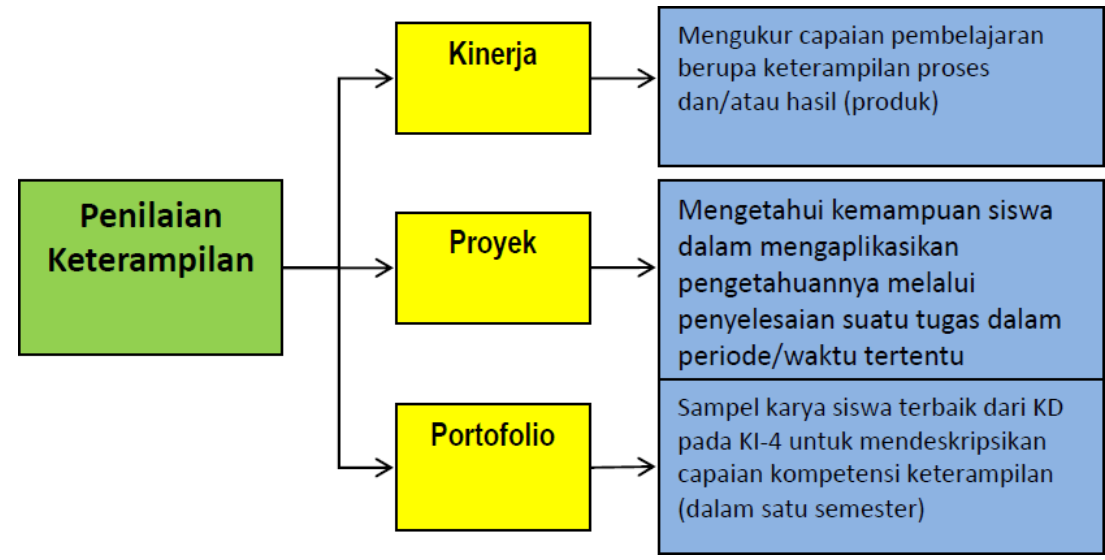

Gambar 2.4 Teknik Penilaian Keterampilan

${ }^{43}$ Kemendikbud, Panduan Penilaian..., 15-16.

${ }^{44}$ Kemendikbud, Panduan Penilaian..., 21. 


\section{Jurual Dirosah Islamigah}

Volume 4 Nomor 2 (2022) 226-249 P-ISSN 2656-839x E-ISSN 2716-4683

DOI: 10.17467/jdi.v4i2.909

\section{DAFTAR PUSTAKA}

Abdul Majid \& Dian Andayani, Pendidikan Agama Islam Berbasis Kompetensi Konsep Dan Implementasi Kurikulum 2004, (Bandung: PT Remaja Rosdakarya, 2004).

Abdul Majid. Perencanaan Pembelajaran : Mengembangkan Standar Kompetensi Guru. cet 7. Remaja Rosdakarya. Bandung. 2011.

Afnil Guza, (2008), Undang-undang Sisdiknas dan Undang-undang Guru dan Dosen, Jakarta: Asa Mandiri

Ahmad Tafsir, Metodologi Pengajaran Agama Islam, Remaja Rosdakarya, Bandung, 1995.

Ahmad, Zainal Arifin. 2012. Perencanaan Pembelajaran dan Desain sampai Implementasi. Yogyakarta: Pustaka Intan.

Alisuf, M Sabri. 1999. Ilmu Pendidikan. (Jakarta: CV. Pedoman Ilmu Jaya).

Arief, Armai (2002). Pengantar Ilmu dan Metodologi Pendidikan Islam. Jakarta: Penerbit Ciputat Pers.

Arifin, M. (2000). Kapita Selekta Pendidikan (Islam dan Umum), Jakarta: BumiAksara.

Arifin, Zainal. 2017. Evaluasi Pembelajaran Prinsip, Teknik, Prosedur. Bandung: Remaja Rosdakarya.

Basyiruddin Usman, Metodologi Pembelajaran Agama Islam, Jakarta:Ciputat Pers, 2002

Brown, H-Douglas. 2007. Principles of Language Learning and Teaching. London: Longman.

Depdiknas .2006. Permendiknas No 22 Tahun 2006 Tentang Standar Isi. Jakarta : Depdiknas.

Dewi Salma Prawiradilaga, Prinsip Desain Pembelajaran, Kencana Prenada Media Group, 2007

Fatah Syukur., Teknologi Pendidikan, (Semarang : Rasail, 2008).

Kemendikbud .(2016). Permendikbud Nomor 22 Tahun 2016 Tentang Standar Proses Pendidikan Dan Menengah. Jakarta: Kemendikbud

Kemendikbud. 2015. Panduan Penilaian untuk Sekolah Menengah Pertama. Jakarta: Direktorat Jenderal Pendidikan Dasar dan Menengah

Marwiyah, St., Alauddin. 2015. Perencanaan Pembelajaran Pendidikan Agama Islam. Makassar: Aksara Timur.

Mudhafir, Fadhlan. (2000). Krisis Dalam Pendidikan Islam, Jakarta: Al-Mawardi Prima.

Munthe, Bermawi. 2012. Desain Pembelajaran. Yogyakarta: PT Pustaka Insan Madani. Nasir A. Baki,Metode Pembelajaran Agama Islam, (Makasar: Alauddin Press, 2012)

Permendiknas No. 41 Tahun 2007 tentang Standar Proses Untuk Satuan Pendidikan Dasar dan Menengah.

Ramayulis. (2013). Profesi dan Etika Keguruan. Jakarta: Kalam Mulia.

Sugiyono. (2016). Metode Penelitian KOMBINASI (Mixed Methods). Bandung: ALFABETA

Suparno, Paul, Teori Perkembangan Kognitif Jean Piaget, Kanisius, Yogyakarta, 2001. 


\section{Jurual Dirosah Islamiyah}

Volume 4 Nomor 2 (2022) 226-249 P-ISSN 2656-839x E-ISSN 2716-4683 DOI: $10.17467 /$ jdi.v4i2.909

Tohirin. (2012). Metode Penelitian Kualtatif dalam bimbingan dan konseling. Jakarta: Raja Grafindo Persada.

Uno, Hamzah B. 2006. Perencanaan Pembelajaran. Jakarta : Bumi Aksara.

Yaumi, Muhammad. Prinsip-Prinsip Desain Pembelajaran. Jakarta: Kencana Media Grup, 2013. 